\title{
REEXAMINATION OF LUCAS PARADOX: GRAVITY MODEL APPROACH FOR BRICS COUNTRIES1
}

\author{
Harun BAL ${ }^{2}$ \\ Emrah Eray AKÇA ${ }^{3}$ \\ İpek TEKİN4 \\ Mina Mahjoub LALEH ${ }^{5}$
}

\begin{abstract}
Although the neo-classical theory argues that capital should flow from developed countries to the developing countries until the marginal return of investment among countries is equalized, Lucas (1990) reached the conclusion that such capital flows have not occurred from US to India even though the marginal return of capital in India is about 58 times that of US. Lucas explained this paradoxical finding as of stemming from primarily human capital differences, external benefits of human capital and capital market imperfections. Lucas's paradoxical findings brought intense debates with it on the subject and led to researches on other determinants of capital flows. In accordance with these discussions, our study questioned the existence of Lucas Paradox for BRICS countries (Brazil, Russia, India, China, South Africa) using panel data for 2002-2014 period. Findings obtained from the Augmented-Gravity model confirm the existence of Lucas Paradox in BRICS countries. In other words, marginal return of capital is not an important determinant of capital inflows towards BRICS countries. The general conclusions of the study show that capital inflows depend on institutional quality, agglomeration effect, trade openness degree, exchange rate and volatility of inflation.

Keywords: Capital Movements, Foreign Direct Investments, Lucas Paradox, Gravity Model, BRICS.

\section{LUCAS PARADOX'UNUN YENIDEN İNCELENMESİ: BRICS ÜLKELERİ İÇIN ÇEKIMM MODELİ YAKLAŞIMI}

ÖZ

Neo-klasik teorinin, ülkeler arasında yatırım getirileri farklılı̆̆ı ortadan kalkıncaya kadar sermayenin gelişmiş ülkelerden gelişmekte

\footnotetext{
1 This article was presented in International Congress of Management Economy and Policy taken place in Istanbul in 26-27 of November, 2016.

2 Prof., Çukurova University, Department of Economics, harunbal@cu.edu.tr, ORCiD: 0000-0003-0878-8253

3 Res. Asst., Çukurova University. Department of Economics, eakca@cu.edu.tr ORCID: 0000-0003-4190-5503

4 Res. Asst., Çukurova University, Department of Economics, itekin@cu.edu.tr, ORCID: 0000-0001-8547-9185

${ }^{5}$ Dr., Çukurova University, Department of Economics, mina_mahjoub@yahoo.com
} 
olan ülkelere akması gerektiği tezini Hindistan ve ABD için analiz eden Lucas (1990), Hindistan'da sermayenin marjinal getirisinin $A B D^{\prime}$ dekinin yaklaşı 58 katı olmasına rağmen $A B D^{\prime}$ den Hindistan'a doğru böyle bir sermaye akımının gerçekleşmediği bulgusuna ulaşmışıtır. Lucas, bu paradoksal bulguyu; beșeri sermaye farklıllkları, beşeri sermayenin dişsal faydaları ve sermaye piyasası eksiklikleri olmak üzere üç etkene bağlı olarak açılklamaktadır. Lucas'ın paradoksal bulguları konu üzerinde yoğun tartışmaları beraberinde getirmiş ve sermaye akımlarının başka belirleyicileri üzerine araştırmalara yol açmış̦tır. Bu tartışmalardan esinlenerek hazırlanan bu çalış̧mada, 2002-2014 dönemi panel verileri kullanılarak BRICS ülkeleri (Brezilya, Rusya, Hindistan, Çin, Güney Afrika) için Lucas Paradoksu'nun varlığı sorgulanmıştır. Bu doğrultuda çekim modeli aracılığıyla ikili doğrudan yabancı sermaye akımlarının incelendiği çalışmanın analiz sonuçları, BRICS ülkelerinde Lucas Paradoksunun varlı̆̆ını doğrulamaktadır. Bir diğer ifadeyle, BRICS ülkelerine yapılan doğrudan yabancı yatırımlarda sermayenin marjinal getirisinin önemli bir belirleyici olmadığı sonucuna varılmıştır. Çalışmadan elde edilen genel sonuçlar BRICS ülkelerine yapılan doğrudan yabancı yatırımların kurumsal kaliteye, yığllma etkisine, ticarete açılklk derecesine, döviz kuruna ve enflasyondaki oynaklığa bağlı olduğunu göstermektedir.

Anahtar Kelimeler: Sermaye Hareketleri, Doğrudan Yabancı Yatırımlar, Lucas Paradosku, Cekim Modeli, BRICS.

\section{Introduction}

The practices of financial liberalization pioneered by developed countries, have became widespread around all the world associated with liberal policy practices of developing countries (DCs) in 1980s. The main reason of DCs' policies towards financial liberalization is the desire of these countries to reach the capital they need in the economic development process. In this context, DCs competing with each other to attract foreign capital have considerably lifted their capital controls and put into effect policy implementations to remove social, political and economic obstacles against foreign investments. An important part of these implementations are towards domestic labor market conditions, corporate taxation, tariff barriers, subsidies, privatizations and regulatory regime policies. Foreign capital investment is an important factor affecting growth performance, employment rates, prosperity level and global competitive power of countries. Among 
foreign investments, foreign direct investment (FDI) is especially crucial. It is emphasized that FDI which may play an important role in economic growth process not only provide the capital needed by the countries, but also increase production, exports, employment and productivity. Besides, FDI gives rise to transfer of technology and management skills among countries (Agiomirgianakis, Asterio and Papathoma, 2003; Jadhav, 2012).

DCs by putting into effect the incentives and policy regulations aimed to attract such investments towards their domestic market due to the increasing importance of FDI have not attained desired results from the implemented policies for some periods because of various constraints. Yet, these developments have not diminished the interest for FDI; on the contrary, the rigidities in the credit markets due to the recent economic crisis have increased the importance of FDI (Sarısoy and Koç, 2010). In addition, since industrialized countries pulled out of the market of global manufacturing production as a result of their structural transformation in the 1970s and 1980s DCs were encouraged to attract production and FDI in manufacturing sector. Although this competitive environment has led to accelerating liberal policies of DCs, the location choices of FDI has not responded quickly and significantly to these changes (Demiral et al., 2015).

According to Neoclassical theory capital should flow from the rich (developed) countries that have more physical capital per worker to the poor (developing) ones having relatively less physical capital per worker. This hypothesis is based on the fact that the return of capital in the rich countries is relatively low compared to the poor ones. But, Lucas (1990) concluded that there is no capital flow in this direction at the level predicted by Neoclassical theory. Lucas's finding is called as Lucas Paradox in the economic literature. Lucas (1990) stated that such a capital flow from United States (US) to India has not occurred, although the marginal return of the capital in India is about 58 times that of the US. Lucas' findings have raised arguments on other determinants of FDIs as well as the marginal return of capital. Considering a number of other factors, as the lack of qualified workforce, inadequate infrastructure, high level of corruption, and the difficulties they have with regard to repaying foreign debts, it is seen that DCs' risk adjusted return rates have declined substantially (Prasad et al., 2007). In addition, the fact that FDI toward China where the restrictions on capital movements were 
heavily implemented in the 1990s are more than that of towards liberal economies has led to a discussion of different determinants of FDI in the literature. At this point, many other factors such as market size, trade openness, exchange rate, economic stability, institutional quality, infrastructure, labor costs, tax rates and political stability have become widespread as determinants of FDI in the literature (see Asiedu, 2002; Walsh and Yu, 2010).

The remainder of this study is organized as follows: After the theoretical explanations related to FDI and Lucas Paradox are included in the first part, the empirical literature is presented in the second part. Following the third part including the dataset, methodology and empirical findings on Lucas Paradox and thus determinants of FDI in BRICS countries, our study is completed with fourth part including results and evaluations.

\section{Theoretical Background: Foreign Direct Investment and Lucas Paradox}

FDI consists of investments in physical production means as buildings and factories as well as financial resources which is defined as enterprises in which foreigners have at least 10 percent share of dividend or voting. FDI is carried out by multinational corporations (MNCs). MNCs, defined as enterprises that conducts its production and/or marketing activities in two or more countries have its own business strategy, management conception, and it applies its own strategies within its all affiliates and subsidiaries. MNCs realize FDI due to several reasons as penetrating to the market, accessing to raw materials and intermediate inputs, reducing of labor costs, accessing to technology, reducing the tax burden, overcoming with customs barriers, diversification of investments at international dimension and overcoming transportation costs (IMF, 2004).

Among the FDI that is realized in different ways, new investments (greenfield investments) create more added value in the market. So, the host countries lean towards this type of FDI. New investments emerging by foundation of a new production facility in a foreign country may also necessarily arise as a result of supervisions carried out in the host country. The merger and acquisition (M\&A) which is another type of FDI could be realized in two ways: One of them is the exchange of dividend between two similar sized companies in order to increase their market power or productivity. Second one is a large company purchasing of a significant part of the 
assets belonging to a small company. Privatization which is an another type of FDI is defined as the selling of public sector equities to real or corporate entities (Görmezöz, 2007).

The most important theories explaining the FDI are the product cycle theory, oligopolistic reaction theory, OLI model, and theory of horizontal and vertical integration investments. In the product cycle theory developed by Vernon (1966), production process is divided into three main stages as product development, maturation and standardization. It is stated that in the standardization phase, the product reaches to a stage that it could be produced in foreign countries. According to the oligopolistic reaction theory, firms tend to invest directly in foreign markets which the same market with their rivals in anticipation of possibility that their competitors may take over the market by investing in foreign markets. According to the OLI model developed by John Dunning (1980) which focuses on ownership, location and internalization as determinants of FDI, the firms should firstly have production privileges that provide efficiency in the foreign market. Secondly, they should have some advantages such as low cost production and low transportation costs. Thirdly, they should have a broad market network on marketing, management and property control (Wadhwa, 2011). Horizontal integration investment is known as production of MNCs in foreign markets by using their monopolistic advantages in product differentiation in order to compete with domestic firms. Vertical integration investment is production of a product in several different countries as a result of dividing into several stages of the production process of the final goods produced by the MNCs. Vertical integration investments have been widespread rapidly due to the fact that exports lead to high transportation costs (Protsenko, 2003).

Studies testing determinants of FDI focus on a lot of factors such as market size, trade openness, exchange rate, economic stability, institutional quality, infrastructure, labor costs, tax rates and political stability. Regarding the extent to which these factors are taken into consideration, it is very important to realize the aim of FDI. In this context, it is important to identify the difference between market-seeking FDI and non-market seeking FDI. In the marketseeking FDI the goods that were produced in the host country are sold again in the domestic market of that country. Therefore, domestic demand enhancing factors as the high income level and the large market size of the host country could direct to market-seeking 
FDI. In the non-market seeking FDI, the goods produced in the host country are sold abroad. For this reason, the effect of the domestic demand increasing factors of FDI in the host country remains low (Asiedu, 2002, p. 109). It is stated in the literature that a large part of the FDI occurs due to the market-seeking behaviour particularly FDI in high income countries (Jadhav, 2012).

\subsection{Lucas Paradox}

In the context of a production function with constant returns to scale that homogeneous labor and capital inputs are used given the two countries that produce the same product, difference in the amount of production per worker in these two countries could be explained by difference in the amount of capital per worker. The law of diminishing returns refers to that marginal productivity of capital is higher in less productive (relatively poorer- having low production per worker) economies. Accordingly, under perfect competition and free market conditions, new foreign investments will only tend towards poorer economies until the differences between the capitallabor ratios and therefore the wage and capital gains (interest, profit, dividend income etc.) are equalized. In practice, it is showed that the capital flows from rich countries to poor ones are very inadequate when compared with those predicted in theory. According to Summers and Heston (1988) calculations, per capita production in the US is about 15 times higher than in India. In both countries it is assumed that there is a Cobb-Douglas production function with constant returns of scale:

$$
y=\mathrm{Ax}^{\beta}
$$

In Equation 1; $\mathrm{y}, \mathrm{A}$ and $\mathrm{x}$ shows the production per worker, the level of technology and the amount of capital per worker respectively. Accordingly, the marginal productivity of capital $\mathrm{r}=\mathrm{A} \beta \mathrm{x}^{\beta-1}$ can be obtained in terms of capital per capita and hence per capita production as follows:

$$
\mathrm{r}=\beta A \mathrm{x}^{1 / \beta} \mathrm{y}^{(\beta-1) / \beta}
$$

Calculations of Lucas based on Equation 2 for 1909-1958 period show that the marginal productivity of capital in India is about 58 times that of US. According to Neoclassical arguments, the existence of such a large return differences between the two countries suggests that capital flows should be directed towards 
India and other developing (poor) countries from US and other developed (rich) countries. On the contrary, the fact that capital movement has not actually taken place in this direction is called as Lucas Paradox. Lucas explained this paradoxical finding as of stemming from primarily human capital differences, external benefits of human capital and capital market deficiencies. In Lucas's analysis in which labor input per capita is equal in all countries, the qualitative differences (human capital) between labor units are not taken into account. Lucas has revised his work by taking into account the differences in human capital between the US and India and has concluded that the marginal productivity of capital in India was about 5 times than of the US. Yet, this result has not completely removed the paradox. At this point, Lucas emphasizing the external benefits of human capital revised the production function as follows:

$$
y=\mathrm{Ax}^{\beta} \mathbf{h}^{\lambda}
$$

In Equation 3; $\mathrm{y}, \mathrm{x}$ and $\mathrm{h}$ show production per qualified worker, the amount of capital per qualified worker and the human capital per worker. $\mathrm{H} \gamma$, which is interpreted as an external effect in the equation, increases the efficiency of the workforce just like technology. Accordingly, the marginal productivity of the capital can be expressed as:

$$
\mathrm{r}=\beta A^{1 / \beta} \mathrm{y}^{(\beta-1) / \beta} h^{\lambda / \beta}
$$

According to Krueger (1968) 's calculations, a worker in US produces at such an efficiency equivalent to five workers in India. According to the results of analysis considering this finding, the ratio of the marginal returns of the capital in the US and India is 1.04. Therefore, the returns difference between the two countries disappear completely by including the external effects of the human capital into the models.

Finally, Lucas (1990) focuses on the capital market imperfections and asymmetric information to explain the paradox. Accordingly, the capital inflows to relatively underdeveloped (poor) countries occur with the expectation that they will create an income flow in the opposite direction in the next periods. For example, in response to investments to developing country $\mathrm{B}$ carrying out by developed country A, country A aims to get various incomes such as interest income, dividend income or profit. Such flows for properly taking place among countries depends on the existence of competitive equilibrium conditions. This requires an effective 
mechanism for the fulfillment of international borrowing agreements (investment contracts). Otherwise, after the investment has taken place and profit transfers begin, country B may be profitable by breaking up with country A. Of course in such a case country A will tend not to invest in country B again. Such capital market imperfections are generally called as political risk. Also, if foreign investors have incomplete information about the domestic market of the country in which they conduct investment activities, capital flows will not be realized as far as difference in returns are equalized.

\subsection{The View of Foreign Direct Investments}

In historical perspective, the total World FDI peaked at 1 trillion 902 billion dollars in 2007. Following the global economic and financial crisis of 2008-2009, FDI at global level increased by $38 \%$ when compared with 2014 and reached the highest level of 1 trillion 762 billion dollars in 2015. The most important part of this increase is the M\&A investments in foreign countries. The value of these investments was $\$ 721$ billion in 2015, \$ 432 billion in 2014 . Behind this increase in M\&A are institutional arrangements such as tax regulations. According to official statistics, the value of greenfield investment reached its highest level in 2015 with $\$ 766$ billion (UNCTAD-WIR, 2016). In Figure 1 below, the development trend of FDI in the period 1990-2015 is showed in terms of whole world and various country classifications.

\section{Figure 1. Foreign Direct Investment Inflows}

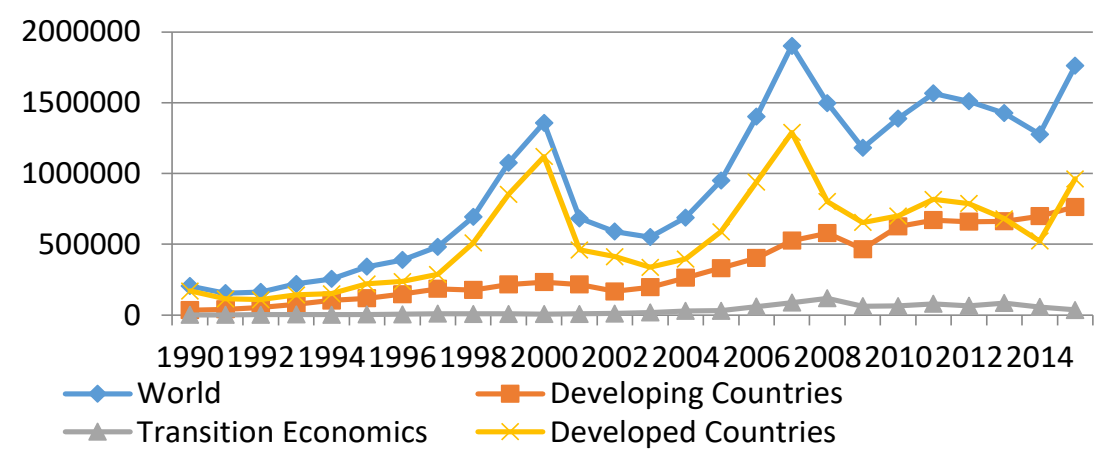

Source: UNCTAD (2016).

Note: The values are in million dollar with nominal prices. 
As seen in Figure 1, FDI has shown a significant upward trend since the mid-1990s. An another point to draw attention is that total FDI exhibits a sharp decline following the crisis years. The fact that the trend of total FDI is similar to that of the developed countries can be interpreted as an indication of that the countries attracted FDI are mostly developed countries. FDI value in developed countries was 522 billion dollars in 2014. They reached 962 billion dolars in 2015 with an increase of 84 percent accounting for more than half of total FDI in the world. An important part of this strong growth in investments has been seen in Europe. FDI in US increased about four times in 2015 after the low level in 2014. Thus, the share of developed economies in total FDI inflows has increased to $55 \%$ in 2015 from 41\% in 2014. Therefore that five-year success of DCs and transition economies which were the main host countries of FDI inflows in 2010-2014 period seems to have turned in favor of developed countries in 2015. An important part of this change stems from serious increase in M \& A investments in developed countries, especially in the US. Net value of M \& A in the US was \$ 17 billion in 2014 , reached $\$ 299$ billion in 2015. Such investments have also increased in Europe by $36 \%$ in 2015 when compared to 2014 .

FDI inflows in DC has reached the highest level with 764 billion 670 million dollars increasing by $9 \%$ in 2015 related to 2014 . DCs in Asian region where 541 billion dollars FDI was actualized in 2015 were the most important host countries of FDI inflows around the world. In this respect, Europe is second with 504 billion dollars of FDI, North America is third with 429 billion dollars, Latin America and the Caribbean is fourth with 168 billion dollars of FDI and Africa is fifth with 54 billion dollars of FDI. FDI in the transition economies was about 35 billion dollars by declining in comparison with 2014 . 2014 is the only year when DCs left behind developed countries in terms of FDI inflows. It is remarkable that five of the top 10 countries (China, Hong Kong, Singapore, Brazil and India) in terms of FDI inflows are DCs. However, when considered as a whole it is stated that the DCs' share is still well below that of expected level (UNCTADWIR, 2016).

The five countries (Brazil, Russia, India, China and South Africa) which had a rapid growth in 2000s and called as BRICS countries draw attention due to their successful performance during recession period of the world economy after 2008 global crisis. The 
remarkable performances of BRICS countries are also influenced by FDI inflows towards these countries. Figure 2 presents net FDI inflows towards BRICS countries in the 1992-2015 period.

Figure 2. Foreign Direct Investment Inflows to BRICS

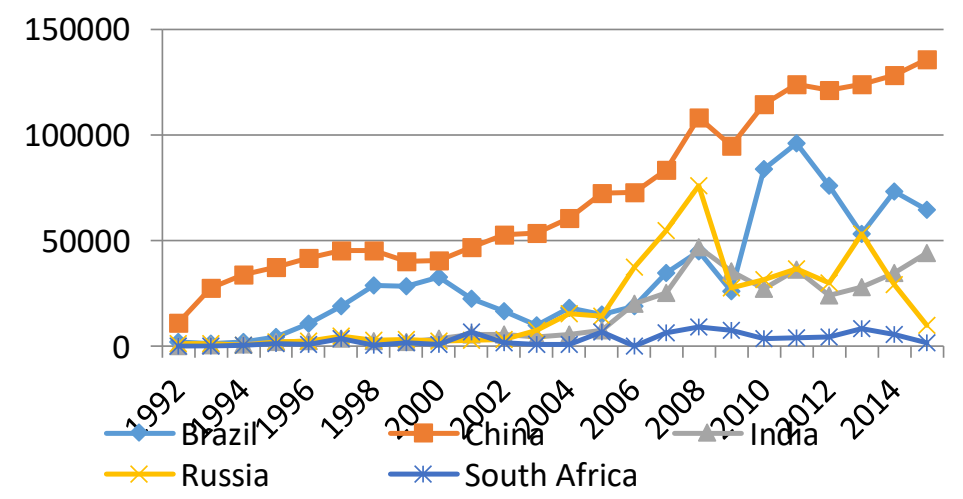

Source: UNCTAD (2016).

Note: The values are in million dollar with nominal prices.

As can be understood from Figure 2, FDI inflows in China are incomparatively more than other BRICS countries. While there is an overall upward trend in China, the most volatile FDI inflows are in Brazil and Russia. The successful performance of China in this regard has been manifested by the introduction of the Chinese effect to literature on the determinants of FDIs. BRICS economies as a whole constitute approximately $20 \%$ of total FDI inflows. The low-cost labor force in China, the young population in India and the natural resource equipment in Brazil and Russia are shown as the main reasons for the FDI inflows towards BRICS economies. As well as China having the cheapest labor force, its large market and attractive policy implementations play an important role for FDI inflows to this country. The significant part of FDI inflows in China is concentrated in industries such as telecommunications, automotive and petrochemicals (Nistor, 2015).

Developed countries actualized approximately $\$ 1$ trillion of FDI outflows (72\% of total FDI outflows) in 2015. In this respect, Europe is the region having the most FDI outflows with 576 billion 
dollars. On a country-by-country basis, the US is the country having the most FDI outflows with $\$ 300$ billion. US is followed by Japan with 129 billion dollars and China with 128 billion dollars. In general, FDI outflows of DCs and transition economies has decreased. The main reasons for this decrease are the decline in commodity prices, the devaluation of the country's national currencies and geopolitical risks. In 2015, more than 50\% of M\&A outflows ( $\$ 388$ billion) are towards manufacturing industry. Investments in the primary sector have declined especially due to the downward movement in commodity prices. From the point of view of the global FDI stock, service sector is ranked as first with the share of $64 \%$, manufacturing industry is the second with the share of $27 \%$ and primary sector is third with the share of 7\% (UNCTAD-WIR, 2016).

\section{Empirical Literature Review}

Empirical literature on Lucas Paradox consists of two stages. One is related to testing of paradox whether if it exists for different periods or not -as claimed by Lucas (1990)- and other process is investigation the effects of international capital market imperfections that may lead to paradox as well as fundamental factors that have an impact on marginal product of capital to which paradox could be attributed. In the context of Lucas Paradox, Clemens and Williamson (2000) by analyzing the determinants of capital flows towards a sample of 34 countries with panel data analysis method for the period of 1894-1913 do not find any role of GDP per capita to explain Lucas paradox. Both natural resource endowment and qualitative and quantitative increases in labor have a significant role in determination of capital flows is another finding of the article. By investigating the role of capital market deficiencies Reinhart and Rogoff (2004) state that sovereign default as an indicator of credit market imperfections pose a serious obstacle on capital flows to developing countries. However, the effects of human capital externalities suggested by Lucas (1990) and the role of other "new growth" theory elements will increase if market imperfections decrease in accordance with institutional quality development.

Using data over the period 1997-2001, Lothian (2006) examines as to why capital flows have not occured as expected from developed towards developing countries find that unsustainable price stability, capital controls and weak institutional quality are crucial factors preventing FDI flows. Alfaro, Kalemli-Ozcan and 
Volosovych (2008) make an extensive regression analysis in order to investigate Lucas paradox and its determinants among 98 countries for 1970-2000 period after Bretton Woods. Although the results point to Lucas paradox, once the variable of institutional quality taken into consideration paradox disappears. After that they repeat the analysis with different sub-periods and different social, political and economic variables in order to test whether the effect of institutional quality as an explanatory of paradox is valid for different models or not. They find that institutional quality is robust to be the best explanatory variable of paradox. On the other hand, Azemar and Desbordes (2013) test the robustness of Alfaro et.al.(2008) to outliers with S-estimator by using the same sample and models and found that differences in terms of institutional quality are not effective to eliminate paradox when observations leading to bias in the sample on Botswana, India, Kuwait, Panama, Singapure and Zimbabwe is removed. Similar estimations are conducted by using instrumental variables estimator against endogeneity problem, a quadratic model against potential nonlinearity and considering a more extensive sample of 104 countries and 1970-2007 time period. Although institutional quality contributes to justification of Lucas paradox, it is unable to remove the paradox completely. By iterating the similar analysis Göktan (2015) estimates the effect of initial income per capita, institutional quality, human capital, macroeconomic stability and capital market imperfections on crossborder capital flows directed to banking and nonbank sectors with ordinary least squares method by accounting for cross-section heterogeneity and sectoral diversities. Unlike Azemar and Desbordes (2013) Lucas paradox disappears as country heterogeneities are considered.

In opposition to Alfaro et.al. (2008), Franken and Van Wijnbergen (2010) test Lucas paradox using panel data over the period of 1981-2006 for low income countries and find no evidence of institutional factors having a significant effect to explain Lucas Paradox. Besides, trade openness and natural resource endowment are main variables as a rationale for paradox. By employing panel data method with fixed and random effects estimators Reinhardt et.al.(2013) investigate Lucas paradox for a sample of 110 countries and for 1980-2006 period. The findings are compatible with neoclassical theory once capital account openness level is controlled. Notwithstanding no systematic relationship is found between net 
capital flows and economic development when capital account openness is below median openness level. Probable effects of many factors such as public and private sector components of capital flows, human capital, institutions, financial market imperfections that are mostly used in other studies are also taken into consideration. The significant and strong effect of capital account constraints on capital flows remain unchanged.

For a sample of 57 industrialized and emerging market economies and for the 1990-2011 period Herrmann and Kleinert (2014) investigate the determinants of aggregate capital flows by using Feasible Generalized Least Squares estimator. Contrary to several studies, neoclassical nexus between income per capita and capital flows is valid particularly for Eurozone. They attribute this finding to other studies focusing on emerging markets and using gross capital flows. Using a quarterly dataset up to 64 emerging markets and 1993-2009 period Byrne and Fiess (2016) empirically investigate the determinants of both aggregate and disaggregate capital flows using uniforms spacings approach and panel analysis of nonstationarity in idiosyncratic and common components (PANIC) which let the examination of common factors in capital flows. Longterm interest rates, commodity prices, institutional quality and financial openness are the main determinants of capital flows as findings indicate. Human capital is inadequate to explain Lucas Paradox.

The empirical studies mentioned above are summarized in Table 1. Unlike many empirical studies, this article aims to make a contribution on testing Lucas paradox by considering bilateral capital flows between BRICS and G7 country groups and applying dynamic panel data analysis method in the context of gravity model approach. 


\begin{tabular}{|c|c|c|c|c|}
\hline \multicolumn{5}{|c|}{ Table 1. Overview of Empirical Studies } \\
\hline Study & Countries & $\begin{array}{c}\text { Time } \\
\text { Coverag } \\
\text { e }\end{array}$ & $\begin{array}{c}\text { Methodolog } \\
y\end{array}$ & Results \\
\hline $\begin{array}{l}\text { Clemens } \\
\text { and } \\
\text { Williamso } \\
\text { n (2000) }\end{array}$ & $\begin{array}{l}\text { British and } \\
34 \text { capital } \\
\text { receiving } \\
\text { countries }\end{array}$ & $\begin{array}{l}1894- \\
1913\end{array}$ & $\begin{array}{l}\text { Panel data } \\
\text { analysis } \\
\text { method }\end{array}$ & $\begin{array}{l}\text { GDP per capita } \\
\text { does not have } \\
\text { a role in } \\
\text { explaining } \\
\text { Lucas paradox. }\end{array}$ \\
\hline $\begin{array}{l}\text { Lothian } \\
\text { (2006) }\end{array}$ & $\begin{array}{c}85 \text { less } \\
\text { developed } \\
\text { countries }\end{array}$ & $\begin{array}{l}1997- \\
2001\end{array}$ & $\begin{array}{l}\text { Cross- } \\
\text { country } \\
\text { regressions }\end{array}$ & $\begin{array}{l}\text { Capital flows } \\
\text { are related to } \\
\text { better } \\
\text { institutions. }\end{array}$ \\
\hline $\begin{array}{l}\text { Alfaro, } \\
\text { Kalemli- } \\
\text { Ozcan and } \\
\text { Volosovyc } \\
\text { h (2008) }\end{array}$ & $\begin{array}{c}23 \\
\text { developed, } \\
75 \\
\text { developing } \\
\text { countries }\end{array}$ & $\begin{array}{l}1970- \\
2000\end{array}$ & $\begin{array}{l}\text { Ordinary } \\
\text { Least } \\
\text { Squares } \\
\text { approach }\end{array}$ & $\begin{array}{c}\text { Once } \\
\text { institutional } \\
\text { quality } \\
\text { considered, } \\
\text { paradox } \\
\text { disappears. }\end{array}$ \\
\hline $\begin{array}{c}\text { Franken } \\
\text { and Van } \\
\text { Wijnberge } \\
\text { n (2010) }\end{array}$ & $\begin{array}{l}\text { All } \\
\text { developing } \\
\text { countries }\end{array}$ & $\begin{array}{l}1981- \\
2006\end{array}$ & $\begin{array}{l}\text { Panel data } \\
\text { analysis } \\
\text { method }\end{array}$ & $\begin{array}{l}\text { Lucas paradox } \\
\text { disappears } \\
\text { when country } \\
\text { specific effects } \\
\text { considered. }\end{array}$ \\
\hline $\begin{array}{c}\text { Azemar } \\
\text { and } \\
\text { Desbordes } \\
\text { (2013) }\end{array}$ & $\begin{array}{c}190 \\
\text { countries }\end{array}$ & $\begin{array}{l}1970- \\
2007\end{array}$ & $\begin{array}{l}\text { Instrumenta } \\
\text { l variables } \\
\text { approach }\end{array}$ & $\begin{array}{c}\text { Lucas paradox } \\
\text { exists. }\end{array}$ \\
\hline $\begin{array}{c}\text { Reinhardt } \\
\text { et.al.(2013 } \\
\text { ) }\end{array}$ & $\begin{array}{c}110 \\
\text { countries }\end{array}$ & $\begin{array}{l}1980- \\
2006\end{array}$ & $\begin{array}{l}\text { Fixed and } \\
\text { random } \\
\text { effects } \\
\text { estimators }\end{array}$ & $\begin{array}{l}\text { Neoclassical } \\
\text { theory is valid. }\end{array}$ \\
\hline $\begin{array}{c}\text { Herrmann } \\
\text { and } \\
\text { Kleinert }\end{array}$ & $\begin{array}{c}57 \\
\text { countries }\end{array}$ & $\begin{array}{l}1990- \\
2011\end{array}$ & $\begin{array}{c}\text { Feasible } \\
\text { Generalized } \\
\text { Least } \\
\text { Squares } \\
\end{array}$ & $\begin{array}{l}\text { Neoclassical } \\
\text { theory is valid. }\end{array}$ \\
\hline
\end{tabular}




\begin{tabular}{|c|c|c|c|c|}
\hline (2014) & & & estimator & \\
\hline $\begin{array}{l}\text { Göktan } \\
\text { (2015) }\end{array}$ & $\begin{array}{c}190 \\
\text { countries }\end{array}$ & $\begin{array}{l}1970- \\
2007\end{array}$ & $\begin{array}{l}\text { Ordinary } \\
\text { Least } \\
\text { Squares } \\
\text { approach }\end{array}$ & $\begin{array}{c}\text { Lucas paradox } \\
\text { disappears } \\
\text { when country } \\
\text { heterogeneitie } \\
\text { s considered. }\end{array}$ \\
\hline $\begin{array}{c}\text { Byrne and } \\
\text { Fiess } \\
(2016)\end{array}$ & $\begin{array}{c}64 \\
\text { emerging } \\
\text { markets }\end{array}$ & $\begin{array}{l}1993- \\
2009\end{array}$ & $\begin{array}{l}\text { Uniforms } \\
\text { spacings } \\
\text { approach } \\
\text { and PANIC } \\
\text { estimator }\end{array}$ & $\begin{array}{l}\text { Institutional } \\
\text { quality and } \\
\text { financial } \\
\text { openness } \\
\text { determine } \\
\text { individual } \\
\text { capital flows. }\end{array}$ \\
\hline
\end{tabular}

\section{Empirical Framework}

This article aims to test the validity of Lucas Paradox by handling the subject of FDI flows from G7 to BRICS countries. In line with this purpose gravity models are estimated by Generalized Method of Moments (GMM) estimator. Thus empirical framework is planned as follows: Firstly data and variables are defined, then theoretical explanations on gravity model and GMM are made. After then models are explained and lastly findings are presented.

\subsection{Data and Variables}

Annual balanced panel data of 2002-2014 period for all variables are used in order to test Lucas paradox. Since more updated bilateral panel data for all the variables have not been reached, this period is considered. Table 2 presents variables, their definitions and data sources in detail. The econometric model of this study is determined according to related literature and includes social, economic and political variables. Empirical tests show that econometric model has high explanatory strength. 
Table 2. Definitions and Sources of Variables

\begin{tabular}{|c|c|c|}
\hline Variables & Definitions & Sources \\
\hline FDI & Direct capital inflows per capita, million $\$$ & \multirow[b]{2}{*}{ UNCTAD } \\
\hline TO & $\begin{array}{l}\text { Trade openness: Share of the sum of } \\
\text { bilateral export and import values in GDP. }\end{array}$ & \\
\hline FC & Fixed capital per labor force, million $\$$ & \multirow{3}{*}{$\begin{array}{c}\text { Penn } \\
\text { World } \\
\text { Table } 9.0\end{array}$} \\
\hline $\mathrm{HC}$ & $\begin{array}{l}\text { Human capital index per capita: A } \\
\text { calculation based on schooling duration and } \\
\text { return to education. }\end{array}$ & \\
\hline ER & Exchange rate: National currency/USD & \\
\hline INFVOL & Inflation volatility: CPI minus average of CPI & $\begin{array}{l}\text { World } \\
\text { Bank }\end{array}$ \\
\hline INST & $\begin{array}{l}\text { Political risk index: consists of components } \\
\text { as Voice and Accountability, Political } \\
\text { Stability and Absence of Violence, } \\
\text { Government Effectiveness, Regulatory } \\
\text { Quality, Rule of Law, Control of Corruption }\end{array}$ & $\begin{array}{l}\text { PRS } \\
\text { Group }\end{array}$ \\
\hline
\end{tabular}

\subsection{Model and Methodology}

Gravity models are utilized and estimated by dynamic panel data analysis method within this part of the study. Before findings acquired, theoretical background of gravity model and dynamic panel data analysis are presented here.

\subsubsection{Gravity Model}

Newton's law of gravitation has been an inspiration to gravity model in economics. Economic logic behind the model stands on the variability of economic flows depending on economic activity in home and host country and also on inverse proportionality of economic flows to distance between these two countries. Applied law 
of Newton predict economic flow of $\mathrm{X}_{\mathrm{ij}}$ from home country $\mathrm{i}$ to country j as (Anderson, 2016):

$$
X i_{j}=\mathrm{G} \frac{Y_{i} E_{j}}{D_{i j}{ }^{2}}
$$

Where $G$ is gravity constant, $Y_{i}$ is volume of related economic activity in country $i, E_{j}$ is volume of related economic activity in country $\mathrm{j}$ and $\mathrm{D}_{\mathrm{ij}}$ is distance between country $\mathrm{i}$ and $\mathrm{j}$. While the first application on gravity model has been conducted for the flow of migration to England, first application on trade flows has been conducted by Tinbergen (1962).

Gravity model in Equation 5 transforms into $\hat{X}_{i j}=a Y^{b}{ }_{i} E^{c}{ }_{j} D_{i j}^{\delta}$ when applied together with its constant and exponents. While $\hat{X}$ is estimated value of $\mathrm{X} ; \mathrm{b}, \mathrm{c}$ and $\delta$ are elasticity coefficients of $\mathrm{X}$ to the change in $Y_{i}, E_{j}$ and $D_{i j}$ respectively (Anderson, 2016). Determinants of D which increases transaction costs among countries are factors being expected to affect FDI flows (distance, institutions, infrastructure, mutual trade, macroeconomic uncertainties etc). As assumed by gravity model, once factors defined by $\mathrm{D}$ are absent marginal return of capital is the sole determinant of FDI flows. Current developments on economical foundations of gravity model have led to revision of original gravity model form in accordance with economic structure. Structural gravity model which is situated in mainstream economics and in resource allocation models among economic sectors considerably contribute to measurement of developments of countries in time, results of trade globalization and location of economic activity. Structural gravity model of economic interactions provide a basic characterization of distribution of economic activity between home and host countries (Anderson, 2016).

\subsection{Generalized Method of Moments (GMM)}

The first factor to prefer panel data analysis method is based on econometrics theory that allows us to make an analysis for a country group as BRICS and for a limited time period. Nevertheless OLS estimator for static panel data is consistent in case of $n$ and $t$ converge to infinite, all independent variables are exogeneous and has no correlation with cross-sectional effects. OLS estimator is inefficient for neglecting error components form of the model. Besides, the situation changes once lagged dependent variable was 
added to the model to which dynamic panel data analysis method allows (Asteriou and Hall, 2011, p. 432).

Arellano and Bond (1991) has developed an efficient generalized method of moments (GMM) in which all lagged values are used as instrumental variables. GMM estimator is advantageous as considering endogeneity problem and biased parameters by using appropriate instrumental variables. On the other hand, a hypothesis test on no second order autocorrelation between error terms of first differenced equation has been also developed. Since consistency of GMM estimator depends on not being of second order autocorrelation $\left(E\left(\Delta v_{i t} \Delta v_{i(t-2)}\right)=0\right)$ (Arrelano and Bond, 1991, p. 281; Baltagi, 2005, p. 141).

Secondary factor based on economic theory to prefer dynamic panel GMM in this study is agglomeration effect which has been affirmed as one of the significant determinants of FDI in the literature. This effect is related to FDI flows being affected by past level of investment. Positive externalities and Bandwagon effect are expected in this context. Bandwagon effect originates from new investors' evaluation for past investments as an indicator of an favourable investment climate (Bal and Akça, 2016). In other words, certain investments might consider the level of previous investments with regard to agglomeration effect.

Within that context, by means of $y_{i, t-1}$ is lagged dependent variable, $x_{i t}^{\prime}$ is set of control variables, $u_{i t}$ is error term; generalized form of dynamic panel data models is defined as in Equation 6:

$$
y_{i, t}=\alpha 0 \mathrm{y} \mathrm{i}, \mathrm{t}+\sum_{N=1}^{4} \Theta X^{N}{ }_{i t}+\mu_{i t}+v_{i t}
$$

Where $\mu_{i t}$ is time invariable unobservable country specific effects, $v_{i t}$ random error term, $X_{i t}^{N}$ explanatory variables set, subscripts of $i$ and $t$ are cross-sections and time period respectively.

FDI is only a function of physical capital stock in the estimated first model (Model 1):

$$
D Y Y_{i j t}=\alpha_{\mathrm{i}}+\beta_{1} \mathrm{SS}_{\mathrm{it}}+\mathrm{u}_{\mathrm{ijt}}
$$

In the second step of analysis, human capital index which has been predicted by Lucas (1990) as a determinant of paradox is included within the model due to its external benefits:

$$
D Y Y_{i j t}=\alpha_{\mathrm{i}}+\beta_{1} \mathrm{SS}_{\mathrm{it}}+\beta_{2} B \mathrm{~S}_{\mathrm{it}}+\mathrm{u}_{\mathrm{ijt}}
$$


The last and more extensive third model including variables of trade openness, institutional quality, inflation volatility and exchange rate is formed as in Equation 9:

$$
\begin{aligned}
& D Y Y_{i j t}=\alpha_{\mathrm{i}}+\beta_{1} \mathrm{SS}_{\mathrm{it}}+\beta_{2} B \mathrm{~S}_{\mathrm{it}}+\beta_{1} \mathrm{SS}_{\mathrm{it}}+\beta_{3} T A_{i j t}+ \\
& \beta_{4} K U R U M_{\mathrm{it}}+\beta_{5} D K_{\mathrm{it}}+\beta_{6} E N F_{\mathrm{it}}+\mathrm{u}_{\mathrm{ijt}}
\end{aligned}
$$

where $i(1,2, \ldots, 5), j(1,2, \ldots, 6)$ and $t(2002,2003, \ldots, 2012)$ subscripts are home country, host country and time period respectively.

\subsection{Empirical Findings}

In the first step of this part unit root tests are applied in order to define the integration level of data. For this purpose both Levin, Lin and Chu (LLC) unit root test developed by Levin et al. (2002) for panel and Fisher-PP unit root test for all cross-sections individually considering heterogeneity of countries developed by Choi (2001) are conducted and the results are presented on Table 3.

Table 3. Unit Root Results

\begin{tabular}{|l|c|c|}
\hline \multirow{2}{*}{ Variables } & LLC & Fisher-PP \\
\cline { 2 - 3 } & Statistics (level) & Statistics (level) \\
\hline FDI & $-14.799^{* * *}$ & $128.369^{* * *}$ \\
\hline FC & $-12.5132^{* * *}$ & 46.7635 \\
\hline HC & $-9.05814^{* * *}$ & 32.1731 \\
\hline TO & $-4.04068^{* * *}$ & $98.7839^{* * *}$ \\
\hline ER & $-4.29329^{* * *}$ & 65.4414 \\
\hline INFVOL & $-6.22330^{* * *}$ & 33.1664 \\
\hline INST & $-16.3201^{* * *}$ & $233.361^{* * *}$ \\
\hline
\end{tabular}

Note: ${ }^{* * *}$ and ${ }^{* *}$ are $\% 1$ and $\% 5$ significance level respectively.

According to LLC unit root test results null hypothesis on nonstationarity of the series is rejected for all variables at $5 \%$ significance level which implies stationarity of the series. Fisher-PP test results lead us to reject the null hypothesis for three of the variables. Thus at least one test result shows that the variables are stationary. Based on existing result, gravity models of 7, 8 and 9 are estimated by GMM estimator and results are in Table 4. 


\begin{tabular}{|c|c|c|c|c|c|c|}
\hline \multicolumn{7}{|c|}{ Table 4. Gravity Models Estimation Results } \\
\hline & \multicolumn{2}{|c|}{ Model 1} & \multicolumn{2}{|c|}{ Model 2} & \multicolumn{2}{|c|}{ Model 3} \\
\hline Variables & Coefficient & Prob. & Coefficient & Prob. & Coefficient & Prob. \\
\hline FDI (-1) & $0.145^{* * *}$ & 0.0000 & $0.166^{* * *}$ & 0.0000 & $0.162^{* * *}$ & 0.0000 \\
\hline FC & $1.349^{* * *}$ & 0.0000 & $0.380^{* * *}$ & 0.0030 & 0.408 & 0.4864 \\
\hline $\mathrm{HC}$ & - & - & $0.369^{* * *}$ & 0.0000 & 0.185 & 0.2099 \\
\hline TO & - & - & - & - & $0.540^{* * *}$ & 0.0008 \\
\hline ER & - & - & - & - & $-1.748^{* * *}$ & 0.0000 \\
\hline INFVOL & - & - & - & - & $-0.026^{* *}$ & 0.0213 \\
\hline INST & - & - & - & - & $1.179^{* * *}$ & 0.0042 \\
\hline \multicolumn{7}{|c|}{ Specification Tests } \\
\hline Wald Test & \multicolumn{2}{|c|}{$3395.643^{* * *}$} & \multicolumn{2}{|c|}{$9451.037^{* * *}$} & \multicolumn{2}{|c|}{$111.2014^{* * *}$} \\
\hline $\begin{array}{c}\text { Sargan } \\
\text { Test }\end{array}$ & \multicolumn{2}{|c|}{$(0.449845)$} & \multicolumn{2}{|c|}{$(0.347778)$} & \multicolumn{2}{|c|}{$(0.336610)$} \\
\hline
\end{tabular}

significance level. Probability values for Sargan test are in brackets.

Wald test results in Table 4 shows the strength of independent variables to explain dependent variable. Accordingly, null hypothesis for zero coefficients of explanatory variables is rejected. Sargan test results indicating whether if any correlation between instrumental variables and error terms exists leads to no correlation between them and so no endogeneity problem. In other words instrumental variables are valid according to Sargan test.

According to the estimation results of equation 7, fixed capital stock affects FDI flows positively at 1\% significance level. 1\% increase in physical capital stock, FDI flows increase by almost $1.3 \%$. This result reveals the validity of Lucas paradox for the base model. According to the estimation results of equation 8 in which human capital stock is also controlled, a 1\% increase in human capital index leads to $0.37 \%$ increase in FDI flows. Once human capital is included in the model, the effect of fixed capital stock on FDI flows decreases. Moreover, a 1\% increase in fixed capital stock still increases FDI flows by $0.38 \%$. Estimation results of equation 9 in which other potential determinants of FDI flows are controlled indicate that physical and human capital are not significant determinants of FDI flows to BRICS countries. Indeed results indicate that trade openness and better institutional quality are the main determinants directing 
FDI flows. Increase in exchange rate and inflation representing macroeconomic instability affect FDI flows negatively.

\section{Conclusion}

Neoclassical theory implies that capital should flow from developed (rich) to developing (poor) countries until differences in marginal return of capital among countries disappear. However, in his pioneering work Lucas (1990) concludes no such capital flow occuring from USA to India although marginal return of capital in India is approximately 58 times of USA. Lucas attributes that paradoxal finding to three factors as differences in human capital, external benefits of human capital and capital market imperfections. These findings of Lucas have led to some crucial discussions on the subject in the literature. Current study is inspired from these discussions and investigates Lucas paradox by gravity model approach for BRICS countries (Brazil, Russia, India, China, South Africa) by using panel data for 2002-2014 period.

Gravity model estimation results are summarized as follows: Capital stock affects FDI flows positive and significantly. Accordingly, a $1 \%$ increase in physical capital per capita increases FDI flows by approximately $1.3 \%$. This result implies the validity of Lucas paradox for the basic model. Estimation results of equation 8 in which human capital is also included show that agglomeration effect on FDI flows is stronger than it is in the first model. Moreover human capital affects FDI flows positively. A 1\% increase in human capital raises FDI flows by $0.37 \%$. In case human capital is included in the model, positive effect of physical capital stock per capita on FDI decreases. Besides, a rise of $\% 1$ in physical capital stock still increases FDI flows by $0.38 \%$. Hence, in contrast to neoclassical arguments, an increase in capital stock and thus a decrease in marginal productivity of capital do not cause a reduction in FDI flows. Lucas paradox which is determined for BRICS countries in basic model is not completely disappeared even if it loses power when human capital is considered. Nonetheless Lucas paradox disappears when other determinants are taken into consideration. Estimation results of equation 9 indicate that physical and human capital are not determinants of FDI flows to BRICS countries. While positive effect of agglomeration continues, trade openness and progress in institutional quality are principal determinants directing FDI flows. On the other hand, increases in inflation and exchange rate affect FDI negatively. 
General results acquired from the analysis show that FDI flows towards BRICS countries pay regard to institutional quality within that country group. Thus as an implication, progress in corporate governance particularly in regulation quality, efficiency of government and control of corruption may lead to increase in FDI flows to BRICS countries. Also, positive effect of trade openness on FDI flows might be interpreted as an indicator for a desired result of financial liberalization policies. Apart from these implications, stability of inflation and exchange rate as indicators of macroeconomic stability have great importance in terms of FDI flows.

\section{References}

AGIOMIRGIANAKIS, G., ASTERIO, D. \& PAPATHOMA, K. (2003). The Determinants of Foreign Direct Investment: A Panel Data Study For The OECD Countries, City University Department of Economics Discussion Paper Series, No. 03/06, London, 1-18.

ALFARO, L., KALEMLİ-ÖZCAN, S., \& VOLOSOVYCH, V. (2008). Why Doesn't Capital Flow from Rich to Poor Countries? An empirical investigation. The Review of Economics and Statistics, 90(2), 347-368.

ANDERSON, J.E. (2016). The Gravity Model of Economic Interaction, Boston College and NBRE.

ARRELANO, M. \& BOND, S. (1991). Some Tests of Specification for Panel Data: Monte Carlo Evidence and an application to employment equations, Review of Economic Studies, 58, 277-297.

ASIEDU, E. (2002). On the Determinants of Foreign Direct Investment to Developing Countries: Is Africa Different?, World Development, 30(1), 107-119.

ASTERIOU, D. \& HALL, S.G. (2011). Applied Econometrics. Palgrave Macmillan.

AZÉMAR, C., \& DESBORDES, R. (2013). Has the Lucas Paradox Been Fully Explained?. Economics Letters, 121(2), 183-187.

BAL, H. \& AKÇA, E. E. (2016). Doğrudan Yabancı Sermaye Yatırımlarının Belirleyicileri: Seçilmiş Doğu Asya ve Pasifik Ülkelerinden Ampirik Bulgular, Sosyoekonomi Dergisi, 24(30), 91111.

BALTAGI, B. (2005). Econometric Analysis of Panel Data (3rd ed). John Wiley \& Sons. 
BYRNE, J. P., \& FIESS, N. (2016). International Capital Flows to Emerging Markets: National and global determinants. Journal of International Money and Finance, 61, 82-100.

CHOI, I. (2001). Unit Root Tests for Panel Data. Journal of international money and Finance, 20(2), 249-272.

CLEMENS, M. A., \& WILLIAMSON, J. G. (2000). Where did British Foreign Capital Go? Fundamentals, Failures and the Lucas Paradox: 1870-1913 (No. w8028). National Bureau of Economic Research.

DEMİRAL, M; BAL, H. \& ALGAN, N. (2015). Gelişmekte Olan Ülkeler Küresel Sermayeyi Çekme Konusunda Niçin Başarısız Olmaktadırlar? Balkan Ülkeleri İçin Lucas Paradoksunun Yeniden İncelenmesi, C.Ü. Sosyal Bilimler Enstitüsü Dergisi, 24(1), 13-30.

DUNNING, J. H. (1980). Toward an eclectic theory of international production: Some empirical tests. Journal of international business studies, 11(1), 9-31.

FRANKEN, C., \& VAN WIJNBERGEN, S. (2010). Private Capital Flows to Low Income Countries: Country-Specific Effects and the Lucas Paradox. Available at SSRN 1537004.

GÖKTAN, M. G. (2015). On the Explanation of the Lucas Paradox. Economics Letters, 137, 109-113.

GÖRMEZÖZ, K. K. (2007). Türkiye'ye Doğrudan Gelen Yabancı Sermaye Yatırımlarının İstihdam Üzerindeki Etkileri, Uzmanlık Tezi, Ankara, 17-21.

HERRMANN, S. \& Kleinert, J. (2014). Lucas Paradox and Allocation Puzzle-Is the Euro Area Different? (No. 2014-01). University of Graz, Department of Economics.

IMF- International Monetary Fund (2004). http://www.imf.org/external/np/sta/bop/pdf/diteg20.pdf. (19.04.2018).

JADHAV, P. (2012). Determinants of Foreign Direct Investment in BRICS Economies: Analysis of Economic, Institutional and Political Faktor, Social and Behavioral Sciences, 37, 5-14.

KRUEGER, A. O. (1968). Factor Endowments and ER Capital Income Differences Amoung Countries, Economic Journal, 78, 641659.

LEVIN, A., LIN, C. F., \& CHU, C. S. J. (2002). Unit Root Tests in Panel Data: Asymptotic and Finite-sample Properties. Journal of econometrics, 108(1), 1-24. 
LOTHIAN, J. R. (2006). Institutions, Capital Flows and Financial Integration. Journal of International Money and Finance, 25(3), 358-369.

LUCAS, R. E. (1990). Why Does't Capital Flow From Rich to Poor Countries?, The American Economic Review, 80(2), 92-96.

NISTOR, P. (2015). FDI Implications on BRICS Economy Growth, Procedia Economics and Finance, 32, 981-985.

PENN WORLD TABLE. https://knoema.com/PWT2015/pennworld-table-9-0 (25.04.2018).

PRASAD, E.; RAJAN, R. \& SUBRAMANIAN, A. (2007). The Paradox of Capital: Is Foreign Capital Associated with Economic Growth and, If not, Why Does It Flow "uphill"?, A Quarterly Magazine of the IMF, 44(1), 1-8.

PROTSENKO, A. (2003). Vertical and Horizontal Foreign Direct Investments in Transition Countries, Ph.D. thesis, LudwigMaximilians University Munich.

PRS GROUP. https://www.prsgroup.com/(25.04.2018).

REINHARDT, D., RICCI, L. A. \& Tressel, T. (2013). International Capital Flows and Development: Financial Openness Matters. Journal of International Economics, 91(2), 235-251.

REINHART, C. M. \& ROGOFF, K. S. (2004). Serial Default and the" Paradox" of Rich to Poor Capital Flows (No. w10296). National Bureau of Economic Research.

SARISOY, İ. \& KOÇ, S. (2010). Doğrudan Yabancı Sermaye Yatırımlarının Kurumlar Vergisi Gelirleri Üzerindeki Etkisinin Ekonometrik Analizi, Erciyes Üniversitesi Iktisadi ve İdari Bilimler Fakültesi Dergisi, 36, 133-153.

SUMMERS, R. \& HESTON, A. (1988). A New Set of International Comparison of Real Product and Price Levels: Estimates for 130 Countries, 1950-1985, Review of Income and Wealth, 34, 1-25.

UNCTAD- United Nations Conference on Trade and Development (2016). World Investment Report, Newyork and Geneva, http://unctad.org/en/PublicationsLibrary/wir2016_en.pdf.

UNCTAD- United Nations Conference on Trade and Development(2016).unctadstat.unctad.org/wds/TableViewer/tableV iew.aspx?ReportId=96740 (19.04.2018).

VERNON, R. (1966). International Investment and International Trade in the Product Cycle. The Quarterly Journal of Economics, 80 (2), 190-207. 
WADHWA, K. (2011). Foreign Direct Investment into Developing Asian Countries: The Role of Market Seeking, Resource Seeking and Efficiency Seeking Factors, Canadian Center of Science and Education, 6(11), 219-220.

WALSH, J. P. \& YU, J. (2010). Determinants of Foreign Direct Investment: A Sectoral and Institutional Approach, IMF Working Papers, No. WP/10/187.

WORLD BANK, http://data.worldbank.org/indicator (19.04.2018). 
